\title{
FINANCIAL DEVELOPMENT AND THE EFFECTIVENESS OF MONETARY POLICY: NEW EVIDENCE FROM MALAYSIA
}

\author{
Danie Eirieswanty Kamal Basa ${ }^{1}$, Zulkefly Abdul Karim²*, and \\ Mohd Azlan Shah Zaidi
}

\begin{abstract}
${ }^{I}$ Faculty of Management and Entrepreneurship, University College Sabah Foundation, Kota Kinabalu, Sabah, Malaysia

${ }^{2}$ Center for Sustainable and Inclusive Development, Faculty of Economics and Management, Universiti Kebangsaan Malaysia, Bangi, Selangor, Malaysia

*Corresponding author: zak1972@ukm.edu.my
\end{abstract}

Published online: 30 December 2019

To cite this article: Basa, D.E.K., Abdul Karim, Z., and Zaidi, M.A.S. (2019). Financial development and the effectiveness of monetary policy: New evidence from Malaysia. Asian Academy of Management Journal, 24(2), 21-39. https://doi.org/10.21315/aamj2019.24.2.2

To link to this article: https://doi.org/10.21315/aamj2019.24.2.2

\begin{abstract}
This paper examines the relationship between financial development (FD) and the monetary policy effectiveness (MPE) in Malaysia. Two indicators designate the level of FD, namely liquid liabilities and stock market capitalisation, and gross fixed capital formation are used in estimating the determinants of MPE which is generated using structural vector auto regressive (SVAR) in an open economy approach. Accordingly, an autoregressive distributed lag (ARDL) model is used in examining the effects of FD and gross fixed capital formation on MPE. Using a yearly time series data spanning from 1991 to 2016, the results revealed that there is a cointegration between FD and gross fixed capital formation on MPE. Interestingly, FD has a negatively significant effect on MPE on output and inflation, which indicates that a more developed financial system has hindered the effectiveness of the monetary policy.
\end{abstract}

Keywords: financial development, monetary policy effectiveness, SVAR, ARDL, financial system

\section{INTRODUCTION}

Since 1990s, the Malaysian financial system has showed impressive development in terms of various reforms, liberalisation, and innovation in its role as an effective

(C) Asian Academy of Management and Penerbit Universiti Sains Malaysia, 2019. This work is licensed under the terms of the Creative Commons Attribution (CC BY) (http://creativecommons. org/licenses/by/4.0/). 
and efficient financial intermediation. The rapid development of the financial system is complemented by substantial advancement in business environment and policy practice, in particular the role of monetary policy in the economy in response to financial development (FD). This rapid development in the Malaysian financial system has resulted in issues on whether a more developed FD has improved or otherwise impair the role of monetary policy in the economy.

In line with the financial sector development that has been documented in the Financial Sector Masterplan 2001-2011 (Bank Negara Malaysia, BNM, 2001) and the Financial Sector Blueprint 2011-2020 (BNM, 2011), the monetary policy in Malaysia has experienced several main changes since 1995, in particular from monetary targeting to interest rate targeting. For example, since April 2004, BNM has introduced a new interest rate framework, the Overnight Policy Rate (OPR) to mark the position of monetary policy. The transition to the new interest rate framework is timely given the favourable economic and financial environment and a more advanced financial infrastructure. The new framework is designed to intensify the effectiveness of monetary policy by facilitating delivery of policy rate changes to other market rates and ultimately to major macroeconomic objectives. This new development in Malaysian monetary policy framework raised the question of whether monetary policy is effective or not in stabilising the economy given the growing development in the financial system in Malaysia. This development is due to the fast-growing financial system that exerts direct impact on monetary policy set by BNM.

There are several reasons why the level of FD can affect the effectiveness of monetary policy. Firstly, the financial market clearly plays a vital role in the conduct and delivery of monetary policy. For example, the development of the financial market can influence the channel of monetary policy through changes in the financial prices (asset prices) that subsequently may affect economic activity through the stock market and household balance sheet channel. Secondly, the current development and innovations in the financial market have raised the question of whether monetary policy becomes more effective or otherwise. This is due to the fact that a more developed financial system can offer various financial investment alternatives, and therefore customers will demand less money (holding less cash) and prefer to increase their savings. By holding less money (increase in saving), the financial system has more liquidity and therefore will speed up the transmission of monetary policy and increase the effectiveness of monetary policy. Therefore, this information is crucial to the monetary authority for their clearer understanding of the link between FD and monetary policy effectiveness (MPE). Thirdly, strengthening the financial system, as well as widening the choice of financial instruments may also enhance the role of the financial sector 
in determining economic outcomes. This may cause changes in the framework of monetary policy, such as in communication strategies, adopted in connection with the financial market.

This paper contributes in several ways to the existing literature on FD and MPE. Firstly, since previous studies were mostly focused on developed countries, this present study should fill existing knowledge gap on developing countries through focusing on Malaysia as a case study. The choice was mainly based on the fact that Malaysia's financial system was transformed significantly since the implementation of the first Financial Sector Masterplan (2001-2011). This was further strengthened under the Financial Sector Blueprint (2011-2020). In consequence, the Malaysian financial system has become increasingly more diversified, competitive and resilient, and transformed into a system that is able to offer a diversity of financial products and services to consumers and businesses with enhanced efficient delivery channels. Secondly, in comparison with the previous studies (for example, Kashyap and Stein, 1997; 2000) that mostly focused on bank lending channels of monetary policy on output and inflation, this study extends the analysis by examining the role of liquid liabilities in the financial system and capital market development on MPE. Thirdly, MPE is generated using structural vector auto regressive (SVAR) model by accumulating the response of output growth and inflation rate on monetary policy changes (interest rate and money supply) using impulse-response function. The previous studies on monetary policy in Malaysia, such as Azali and Matthews (1999), Ibrahim (2005), Tang (2006), Karim et al. (2011), Karim and Karim (2014), and Xiaohui and Masron (2014) in China, have not sufficiently examined empirically the effect of FD on MPE. Finally, the autoregressive distributed lag (ARDL) model (bounds test) is used for further investigation into the link between FD (liquid liabilities and stock market capitalisation) and MPE on output and inflation. The main advantage of ARDL model is in its suitability to handle time series data whether stationary at level form $\mathrm{I}(0)$, first different $\mathrm{I}(1)$, mixtures of $\mathrm{I}(0)$ and $\mathrm{I}(1)$, or over short sample periods.

The remainder of the paper is organised as follows. The second (next) section discusses the literature review, while the third section provides an econometric model, namely the SVAR model, to compute MPE and then ARDL whilst examining the role of FD on MPE. The subsequent section summarises the main findings, and the final section concludes and discusses some policy implications. 


\section{LITERATURE REVIEW}

The theoretical study of relationships between FD and MPE can be traced back to Gurley and Shaw (1955; 1967), Taylor (1987), Hendry and Ericsson (1991), Arestis et al. (1992), and Mullineux (1994), among others. In more recent studies, the large body of literature has focused on the credit channel theory as proposed by Bernanke and Gertler (1995) which posits that the higher level of financial frictions is generally associated with stronger transmission mechanism of monetary policy. Previous studies that had examined the links between FD and MPE argued that bank lending channel played a vital role as a channel of monetary policy transmission mechanism. For instance, Kashyap and Stein (1997; 2000) discovered that the channel will come into effect through its influence on loan supply especially when the bank has less liquid balance sheet. Gomez et al. (2005) concluded that monetary policy loses some effectiveness in influencing real variables in the short run, due to the partial dilution of the main monetary transmission channels. Mishra et al. (2012) found that the channel of monetary transmissions tend to be dominated by bank lending rate channel for low income countries with low level of FD. Aysun et al. (2013) and Ciccareli et al. (2015) showed that credit channels were stronger in the face of financial movements as it strengthens the effect of monetary policy shocks on output and inflation.

Empirical studies relating to the role of FD on MPE produced mixed results, where some studies argued that more developed financial markets tend to improve the MPE (for example, Singh et al., 2007, Krause and Rioja, 2006), whereas some studies conversely showed that other markets tend to reduce the MPE (for example, Carranza et al., 2009, and Ma and Lin, 2016). Singh et al. (2007) argued that monetary policy affects prices in the financial system, thus generating an important impact on the MPE. This hypothesis is in parallel with the debates of previous economists such as Meier and Seers (1984). According to Krause and Rioja (2006), the development of the financial sector is related to short-term stabilisation. Based on their empirical studies conducted using financial sector instruments, such as private credit, liquidity liabilities, and monetary aggregate index, they concluded that development of the financial sector has significantly contributed to the implementation of more efficient monetary policy.

Carranza et al. (2009) examined the in-depth relationship between development in the financial sector and the MPE using a sample of more than 60 countries. The main findings showed that there is no general relationship between the development of the financial sector and the MPE. Specifically, the results revealed that the more advanced financial sectors will reduce the effectiveness of monetary policy due to financial innovation. In addition, there is a difference between the 
effect of monetary policy on FD in developing countries relative to advanced ones. The results indicate that the effect of monetary policy on inflation is to strengthen FD in advanced countries, whereas output declines with FD in developing economies. This outcome may be due to the size, capitalisation, and liquidity of the central banks in controlling economic activities. A recent study by Ma and Lin (2016) examined the relationship between FD and MPE using panel data from 41 economies. The main findings indicate that the effect of monetary policy on output and inflation are significantly and negatively correlated with FD which indicates that the MPE declines as the financial system become more developed. This finding is also consistent with that of Cecchetti and Krause (2001) who showed evidence that improvements in the development of the financial sector and financial intermediaries, as measured by the less centralised system of banking, were significantly affecting reduction in inflation and output.

In the Malaysian context, based on our best knowledge, no previous study has examined the link between FD and MPE. The studies conducted were mostly focused on the issues of finance-growth empirics, and the effect of monetary policy on economic activity. Previous studies that supported finance-led growth nexus in Malaysia included Ansari (2002), Ang and McKibbin (2007), Ang (2008), and Karim et al. (2008). Whereas, studies that have examined the role of monetary policy on economic activity included Azali and Matthews (1999), Ibrahim (2005), Tang (2006), Karim et al. (2011), and Karim and Karim (2014). These studies have generally confirmed the real effects of monetary policy in Malaysia. Given this information gap in the literature, this present study will subsequently investigate the link between FD and MPE in Malaysia through using the two econometric model, namely SVAR and ARDL.

\section{METHODOLOGY}

This section discusses the methodology used in investigating the influence of FD and gross fixed capital formation on the MPE. Firstly, the SVAR model was used in generating the MPE (interest rates and money supply) on economic growth and inflation. Secondly, the ARDL model, as proposed by Pesaran and Shin (1995; 1999), was used in examining the impact of the financial sector development and gross fixed capital formation on the MPE. 


\section{MPE}

In most of the literature works on monetary policy, the SVAR methodology was used in identifying monetary policy shocks. With this approach, the dynamic linkage between the variables can be captured using impulse response function, and variance decomposition. Therefore, in order to construct the MPE, this study has considered foreign variables, domestic variables, and policy variables in modelling SVAR for a small-open economy. Specifically, the foreign variables comprised world oil price (WOP), foreign income (Yf), and federal fund rates (FFR). The domestic variables comprised gross domestic output (GDP), inflation rate (INF), and real effective exchange rate (REER) while policy variables included interbank overnight rate (IBOR) and broad money (M3). Quarterly data, sourced from the World Bank and International Monetary Fund (IMF)'s International Financial Statistics, were collected spanning from 1991 to 2016 (26 years or 104 quarters).

In generating MPE from the SVAR model, two steps were involved. Firstly, we estimate the baseline SVAR model in Equation 1. The model can be written as follows:

$$
A_{0} Y_{t}=\Gamma_{0} D_{0}+A(L) Y_{t}+\varepsilon_{t}
$$

where $A_{0}$ is a square matrix which shows the coefficient that interacts directly in the structure between the variables in the system, $Y_{t}$ is a $(8 \times 1)$ matrix that is the vector of system variables or $\left(\Delta_{\text {wop }}, \Delta_{y f}, f f r, \Delta_{g d p}\right.$, infl, ibor,$\Delta_{m 3}$ and $\left.\Delta_{\text {reer }}\right), D_{0}$ is a vector of deterministic variables (constant, trend, and dummy variables), $A(L)$ is a $\mathrm{k}^{\text {th }}$ order matrix polynomial in the lag operator $L\left[A(L)=\left[A_{1} L-A_{2} L^{2}-\ldots-A_{\mathrm{k}} L^{\mathrm{k}}\right]\right]$, and $\varepsilon_{t}$ is a $(8 \times 1)$ vector structural disturbance. Equation 1 cannot be estimated directly to obtain the value of $A_{0}$. However, the identification of matrix $A_{0}$ can be estimated in reduced form as follows:

$$
Y_{t}=A_{0}^{-1} \Gamma_{0} D_{0}+A_{0}^{-1} A(L) Y_{t}+A_{0}^{-1} \varepsilon_{t}
$$

or

$$
Y_{t}=\Pi_{0} D_{0}+\Pi_{1}(L) Y_{t}+\mu_{t}
$$

where $\Pi_{0}=A_{0}^{-1} \Gamma_{0}, \Pi_{1}=A_{0}^{-1} A(L), \mu_{t}=A_{0}^{-1} \varepsilon_{t}$

In this study, the A-structured VAR model was utilised to create identifiers among current parameters (contemporaneous parameters). Thus, the model framework in SVAR in this study is stated as follows: 


$$
\left(\begin{array}{cccccccc}
1 & 0 & 0 & 0 & 0 & 0 & 0 & 0 \\
\alpha_{21} & 1 & 0 & 0 & 0 & 0 & 0 & 0 \\
\alpha_{31} & \alpha_{32} & 1 & 0 & 0 & 0 & 0 & 0 \\
\alpha_{41} & 0 & 0 & 1 & 0 & 0 & 0 & 0 \\
\alpha_{51} & 0 & 0 & \alpha_{54} & 1 & 0 & 0 & 0 \\
\alpha_{61} & \alpha_{62} & \alpha_{63} & \alpha_{64} & \alpha_{65} & 1 & 0 & 0 \\
0 & 0 & 0 & \alpha_{74} & \alpha_{75} & \alpha_{76} & 1 & 0 \\
\alpha_{81} & \alpha_{82} & \alpha_{83} & \alpha_{84} & \alpha_{85} & \alpha_{86} & \alpha_{87} & 1
\end{array}\right]\left[\begin{array}{c}
u_{w o p} \\
u_{y f} \\
u_{f f r} \\
u_{g d p} \\
u_{i n f l} \\
u_{i b o r} \\
u_{m 3} \\
u_{r e e r}
\end{array}\right]=\left[\begin{array}{c}
e_{w o p} \\
e_{y f} \\
e_{f f r} \\
e_{g d p} \\
e_{i n f l} \\
e_{i b o r} \\
e_{m 3} \\
e_{r e e r}
\end{array}\right]
$$

In the equation, $e_{w o p}, e_{y f}, e_{f f r}, e_{g d p}, e_{\text {inf }}, e_{i b o r}, e_{m 3}$ and $e_{\text {reer }}$ are structural disturbance disorders or structural shock disorder of world oil price, foreign output, world interest rate, domestic output, inflation, domestic interest rates, money supply, and real effective exchange rate. Whereas, $u_{w o p}, u_{y f}, u_{f f r}, u_{g d p}, u_{i n f f}, u_{i b o r}, u_{m 3}$ and $u_{\text {reer }}$ are respectively residual shock (s) of the variable. This study also used dummies in the model for the 1997/1998 Asian financial crisis and the impact of the sub-prime in 2008/2009.

The matrix in Equation 5 shows that the WOP was assumed to be completely exogenous in the system, whereas $\mathrm{Yf}$ is assumed to respond contemporaneously with world oil price shocks. The FFR was assumed to respond contemporaneously with WOP and $\mathrm{Y}_{\mathrm{f}}$. This approach in identifying assumptions has been widely used in SVAR models; for example, studies in Kim and Roubini (2000) for its application in the G-7 economies, Berkelmans (2005) for the case of Australia, and Zaidi et al. (2013) for the case of ASEAN-3. Domestic variables and gross domestic product (GDP) were assumed to respond contemporaneously with world oil price, whereas inflation (INFL) was the contemporaneous response to the movement of WOP and domestic output (GDP). This way of identifying assumption was used by Kim and Roubini (2000), Berkelmans (2005), Karim et al. (2013) for the case of Malaysia, and Zaidi et al. (2018) for the case of China's effect on the Malaysian economy.

For monetary policy variable concerning interest rates (IBOR), it was assumed that the central bank set the policy rates following observations on the current level of world oil price, foreign income, federal fund rate, domestic output, and inflation. Money supply (M3) was assumed to respond contemporaneously to domestic output, inflation, and interest rates. This approach in identifying assumption was used by Zaidi et al. (2013), Karim et al. (2013) and Zaidi et al. (2018), and Karim and Karim (2014). Since exchange rate (REER) was considered a fast-moving variable, it was thus assumed that REER also responded contemporaneously to all variables in the system. This approach was used by Zaidi and Fisher (2010), Karim et al. (2013), Karim and Karim (2014), and Zaidi and Karim (2014). The matrix 
in Equation 5 shows that the number of free parameters are fewer than the zero restrictions, which implied that the SVAR model is over identified.

In the second step, following estimation of the baseline SVAR model, the accumulated response of economic growth and inflation succeeding the monetary policy changes (interest rates and money supply) was constructed using impulse response function. This implied that the quarterly series of impulse response function was accumulated on a yearly basis (over 26 years) in generating MPE across ASEAN-3.

\section{The Relationship between FD and MPE}

Three steps were involved in investigating the relationship between the FD and MPE through adopting the ARDL framework as proposed by Pesaran and Shin (1999). In the first step, the bounds testing approach was used in investigating the co-movement (cointegration) between variables as follows:

$$
\begin{aligned}
& \Delta y_{t}=\alpha+\beta_{1} y_{t-1}+\beta_{2} F D 1_{t-1}+\beta_{3} F D 2_{t-1}+\beta_{4} G F C F_{t-1}+\sum_{i=1}^{p} \lambda_{i} \Delta y_{t-i}+ \\
& \sum_{i=0}^{q} \gamma_{1, i} \Delta F D 1_{t-i}+\sum_{i=0}^{r} \gamma_{2, i} \Delta F D 2_{t-i}+\sum_{i=0}^{s} \gamma_{3, i} \Delta G F C F_{t-i}+\varepsilon_{t} \\
& \Delta p_{t}=\alpha+\beta_{1} p_{t-1}+\beta_{2} F D 1_{t-1}+\beta_{3} F D 2_{t-1}+\beta_{4} G F C F_{t-1}+\sum_{i=1}^{p} \lambda_{i} \Delta p_{t-i}+ \\
& \sum_{i=0}^{q} \gamma_{1, i} \Delta F D 1_{t-i}+\sum_{i=0}^{r} \gamma_{2, t-i} \Delta F D 2_{t-i}+\sum_{i=0}^{s} \gamma_{3, i} \Delta G F C F_{t-i}+\varepsilon_{t}
\end{aligned}
$$

where $\Delta$ was the first different notation and $(p, q, r, s)$ was the optimum lag length using Akaike Information Criterion (AIC) or Bayesian Criterion (BIC), while $y_{t}$ and $p_{t}$ were MPE on output and inflation, respectively. These were generated by using SVAR methodology as discussed earlier. Two monetary policy variables, namely money supply and interest rate, were used as dependent variables in examining the MPE on output and inflation. Thus, the baseline model in Equations 6 and 7 was estimated separately while examining the effects of FD upon MPE on output (Equation 6) and MPE on inflation (Equation 7).

In Equations 6 and 7, there are two indicators that represent the level of FD, namely Liquid Liabilities (FD1), and Market Capitalization (FD2) as suggested by Demirgüç-Kunt and Levine (1996), Levine et al. (2000), Levine and Zervos (1996), Beck et al. (2006), Demirgüç-Kunt et al. (2011), and Ma and Lin (2016). Liquid Liabilities indicate the value of financial intermediary credits to the public and private sectors, whereas Market Capitalisation represented the role of stock market as financial intermediaries. In addition, gross fixed capital formation (GFCF) was also considered as a controlling variable in the baseline model due to the fact 
that more capital stock in the economy generally led to more fixed investment which can improve MPE. This indicates that an improvement in business fixed investment, which complemented with monetary policy variables (an increase in money supply or a reduction in interest rates), will amplify the MPE on output. The baseline model in Equations 6 and 7 was estimated using yearly time series spanning from 1991 to 2016.

To test whether cointegration was established or otherwise, the computed Wald test (joint test or F test) from Equations 6 and 7 need to be compared with the critical value (normally for case III) as proposed by Pesaran (2001). If the estimated F-statistics fell above the upper bound of the critical values, then the null hypothesis of no-cointegration is rejected. Likewise, if the estimated F-statistics fell below the lower bound, then the null hypothesis cannot be rejected. If the estimated value fell inside the critical value band, the result is inconclusive. The hypothesis to test whether cointegration exists or otherwise is as follows:

$H_{0}: \alpha_{1}=\alpha_{2}=\alpha_{3}=\alpha_{4}=0$ (there is no cointegration amongst the variables)

$H_{1}: \alpha_{1}=\alpha_{2}=\alpha_{3}=\alpha_{4} \neq 0$ (there is cointegration amongst the variables)

In the second step, on confirmation of cointegration, the long-run relationship between MPE and FD can be estimated using long-run model as follows:

$$
\begin{aligned}
& y_{t}=\alpha+\beta_{0} F D 1_{t}+\beta_{1} F D 2_{t}+\beta_{2} G F C F_{t}+\varepsilon_{t} \\
& p_{t}=\alpha+\gamma_{0} F D 1_{t}+\gamma_{1} F D 2_{t}+\gamma_{2} G F C F_{t}+\varepsilon_{t}
\end{aligned}
$$

where $\alpha$ is intercept, $y$ is MPE on output, $p$ is MPE on inflation, FD1 is liquid liabilities, FD2 is stock market capitalisation, $G F C F$ is the gross fixed capital formation, and $\varepsilon_{t}$ the error term. The dependent variable in Equations 8 and 9 can be decomposed into two parts according to the monetary policy variables used in the SVAR model (money supply or interest rates). For example, the effectiveness of monetary policy on output growth, using money supply and interest rate, can be written as follows:

$$
\begin{aligned}
& y_{t}^{m}=\alpha+\beta_{0} F D 1_{t}+\beta_{1} F D 2_{t}+\beta_{2} G F C F_{t}+\varepsilon_{t} \\
& y_{t}^{r}=\alpha+\beta_{0} F D 1_{t}+\beta_{1} F D 2_{t}+\beta_{2} G F C F_{t}+\varepsilon_{t}
\end{aligned}
$$

where the dependent variables, $y_{\tau}^{m}$ and $y_{\tau}^{r}$ denote the MPE on output growth in response to money supply and interest rate respectively. 
Similarly, the equation of the MPE on inflation using money supply and interest rate can be written as follows:

$$
\begin{aligned}
& p_{t}^{m}=\alpha+\beta_{0} F D 1_{t}+\beta_{1} F D 2_{t}+\beta_{2} G F C F_{t}+\varepsilon_{t} \\
& p_{t}^{r}=\alpha+\beta_{0} F D 1_{t}+\beta_{1} F D 2_{t}+\beta_{2} G F C F_{t}+\varepsilon_{t}
\end{aligned}
$$

where the dependent variables, $p_{t}^{m}$ and $p_{t}^{r}$ denote the MPE on inflation in response to money supply and interest rate respectively.

Specifically, the long run model ARDL $(p, q, r, s)$ is estimated as follows:

$$
\begin{aligned}
& y_{t}=\alpha+\sum_{i=1}^{p} \alpha_{i} \Delta y_{t-i}+\sum_{i=0}^{q} \omega_{i} \Delta F D 1_{t-i}+\sum_{i=0}^{r} \gamma_{i} \Delta F D 2_{t-i}+\sum_{i=0}^{s} \theta_{i} \Delta G F C F_{t-i}+\varepsilon_{t} \\
& p_{t}=\alpha+\sum_{i=1}^{p} \alpha_{i} \Delta p_{t-i}+\sum_{i=0}^{q} \omega_{i} \Delta F D 1_{t-i}+\sum_{i=0}^{r} \gamma_{i} \Delta F D 2_{t-i}+\sum_{i=0}^{s} \theta_{i} \Delta G F C F_{t-i}+\varepsilon_{t}
\end{aligned}
$$

The long-run models in Equations 14 and 15 are important in generating the error correction term (ECT), in which the error correction from long-run model is used to estimate the short-run model. Thus, the ARDL specification of the short-run dynamics can be derived by constructing an error correction model (ECM) of the following form:

$$
\Delta y_{t}=\alpha+\sum_{i=1}^{p} \varphi_{i} \Delta y_{t-i}+\sum_{i=0}^{q} \omega_{i} \Delta F D 1_{t^{-i}}+\sum_{i=0}^{r} \gamma_{i} \Delta F D 2_{t^{-i}}+\sum_{i=0}^{s} \theta_{i} \Delta G F C F_{t-i}+
$$
$\phi E C T_{t-1}$

$$
\begin{aligned}
& \Delta p_{t}=\alpha+\sum_{i=1}^{p} \varphi_{i} \Delta p_{t-i}+\sum_{i=0}^{q} \omega_{i} \Delta F D 1_{t-i}+\sum_{i=0}^{r} \gamma_{i} \Delta F D 2_{t-i}+\sum_{i=0}^{s} \theta_{i} \Delta G F C F_{t-i}+ \\
& \phi E C T_{t-1}
\end{aligned}
$$

All coefficients of short-run equation relating to the short run dynamics of the model convergence to equilibrium and $\phi$ represent the speed of adjustment. Theoretically, the value of $\phi$ is negative but cannot exceed -1 .

In the third and final step, the stability of the long run coefficient was examined together with short run dynamics based on Pesaran and Shin $(1995 ; 1999)$. We thus applied the cumulative sum of recursive residuals (CUSUMQ) as proposed by Brown et al. (1975). The CUSUMQ test basically uses the cumulative sum of recursive residual and subsequently plotted against the break points. The structural stability test is conducted by employing the CUSUMQ. If the plot of CUSUMQ 
remains within the critical bound at 5\% significance level, the null hypothesis, that all the coefficients and the error correction model are stable, cannot be rejected. Likewise, if the two lines are crossed, the null hypothesis of coefficient constancy can be rejected at $5 \%$ level.

\section{EMPIRICAL RESULTS}

As stated in the introduction, this paper aims to examine the relationship between FD and MPE on output and inflation in Malaysia. MPE is generated using impulse response function by aggregating the response of output and inflation rate on monetary policy variables (interest rate and money supply) using structural VAR model. Since the main concern is to generate the MPE, the full results of the impulse response function are therefore not reported here but are available upon request.

Table 1 shows the results for bound testing, which clearly indicate that the computed F-statistics is higher than the upper bound critical value at $1 \%$ significance level. This confirms the presence of cointegration (long-run relationship) between explanatory variables (indicators of FD and gross fixed capital formation) and MPE. The results show that in the long run, all variables tend to move together, wherein the explanatory variables (indicators of FD and GFCF) tend to move together to reach the long run equation of MPE as dependent variables.

The empirical results for long run model are summarised in Table 2. The significance of FD variables that appear to influence MPE are liquid liabilities, stock market capitalisation, and gross fixed capital formation as controlling variables in the model. The results show strong negative relationship between FD and MPE on output $\left(y_{t}\right)$ and inflation rate $\left(p_{t}\right)$. This finding indicates that an increase in the level of FD will lead to decrease in MPE. This finding is consistent with those by Krause and Rioja (2006) and Ma and Lin (2016) who argued that greater FD would be associated with a reduction in MPE.

Another interesting finding is that in the long run, there is a negative coefficient of FD indicators (liquid liabilities and stock market capitalisation) on the effectiveness of monetary policy (money supply, $y_{t}^{m}$ and $p_{t}^{m}$; and interest rate, $y_{t}^{r}$ and $p_{t}^{r}$ ). For example, in Table 2 (columns 1 and 2), an increase in liquid liabilities and stock market capitalisation has reduced the MPE on output (money supply as a monetary policy variable). This finding indicates that, the more developed financial system tends to reduce the effectiveness of monetary policy on output. However, in the long run, both FD indicators do not significantly affect MPE on output with 
interest rates as a monetary policy indicator. Both FD indicators have negative coefficients on MPE on inflation (Table 2, columns 3 and 4) regardless of money supply or whether interest rates were used as monetary policy variables. This indicates that the more developed financial system tends to increase the MPE in stabilising the inflation rate. This finding is consistent with the hypothesis that the more developed financial system tends to reduce inflation rate in the economy due to more saving and more substitution between assets. In addition, gross fixed capital formation, as a controlling variable, has positive and significant effect on MPE, which indicates that more fixed investment in the economy can increase MPE in output and inflation.

Table 1

Bound test

\begin{tabular}{|c|c|c|c|c|c|c|c|c|c|c|c|}
\hline \multicolumn{6}{|c|}{ Dependent variable : output, $y_{t}$} & \multicolumn{6}{|c|}{ Dependent variable : inflation, $p_{t}$} \\
\hline \multicolumn{6}{|c|}{ Critical value } & \multicolumn{6}{|c|}{ Critical value } \\
\hline $\begin{array}{l}\text { F- } \\
\text { statistics }\end{array}$ & Value & $\mathrm{k}$ & $\begin{array}{l}\text { Sig. } \\
\text { level }\end{array}$ & $\begin{array}{l}\mathrm{I}(0) \\
\text { bound }\end{array}$ & $\begin{array}{l}\mathrm{I}(1) \\
\text { bound }\end{array}$ & $\begin{array}{l}\text { F- } \\
\text { statistics }\end{array}$ & Value & $\mathrm{k}$ & $\begin{array}{l}\text { Sig- } \\
\text { level }\end{array}$ & $\begin{array}{l}\mathrm{I}(0) \\
\text { bound }\end{array}$ & $\begin{array}{l}\mathrm{I}(1) \\
\text { bound }\end{array}$ \\
\hline$y_{t}^{r}$ & $81.685^{* * *}$ & 3 & $1 \%$ & 3.65 & 4.66 & $p_{t}^{r}$ & $10.559^{* * *}$ & 3 & $1 \%$ & 3.65 & 4.66 \\
\hline$y_{t}^{m}$ & $32.646^{* * *}$ & 3 & $5 \%$ & 2.79 & 3.67 & $p_{t}^{m}$ & $59.217^{* * *}$ & 3 & $5 \%$ & 2.79 & 3.67 \\
\hline
\end{tabular}

Notes: The asterisks $\left({ }^{*}\right),\left({ }^{* *}\right)$, and $\left(^{* * *}\right)$ denote the statistically significant at $10 \%, 5 \%$ and $1 \%$ levels; $\mathrm{y}_{t}=$ MPE on output; $p_{t}=$ MPE on inflation

In terms of error correction (Table 3), which measures the speed of adjustment, all coefficients are negative and statistically significant. To calculate the speed of adjustment, the coefficient of error correction should be normalised, which is (1/ECT). Specifically, for model 1 (column 1), which is the equation of MPE on output (using interest rates as a policy variable), it requires 1.74 years for the system to converge in the long run. In contrast, for model 2 (column 2), the equation of MPE on output (using money supply as a policy variable) a longer time span of 4.32 years is necessary to converge in the long run. For the MPE on inflation (columns 3 and 4) the span of one year and two years were necessary for the respective use of interest rates and money supply as a policy variable. The significance of the error correction terms in all models also indicates that there is a long run causality running from FD indicators and gross fixed capital formation on MPE. 
Table 2

Long-run relationship and error correction term

\begin{tabular}{lccccc}
\hline \multicolumn{3}{c}{ Dependent variable : output, $y_{t}$} & \multicolumn{3}{c}{ Dependent variable : inflation, $p_{t}$} \\
\hline $\begin{array}{c}\text { Independent } \\
\text { variables }\end{array}$ & \multicolumn{1}{c}{$y_{t}^{r}$} & $y_{t}^{m}$ & $\begin{array}{c}\text { Independent } \\
\text { variables }\end{array}$ & $p_{t}^{r}$ & $p_{t}^{m}$ \\
\hline lliq_liab & 0.0026 & $-0.1076^{* * *}$ & lliq_liab & $-0.1053^{* * *}$ & $-0.0953^{* *}$ \\
& {$[0.4603]$} & {$[-3.2223]$} & & {$[-3.8867]$} & {$[-2.5218]$} \\
lstock_markcap & 0.0116 & $-0.0621^{* *}$ & lstock_markcap & $-0.1318^{* * *}$ & $-0.0809^{*}$ \\
& {$[2.1905]$} & {$[-2.1015]$} & & {$[-6.1403]$} & {$[-1.9959]$} \\
lgfcf & -0.0052 & $0.0594^{* *}$ & lgfcf & $0.0881^{* * *}$ & $0.0620^{* *}$ \\
& {$[-1.2426]$} & {$[2.5398]$} & & {$[3.95865]$} & {$[2.145974]$} \\
\hline
\end{tabular}

Notes: The asterisks $\left({ }^{*}\right),\left({ }^{* *}\right)$, and $\left({ }^{* * *}\right)$ denote the statistically significant at $10 \%, 5 \%$ and $1 \%$ levels; the standard errors are in ( ) while t-statistics are in [ ]; $\mathrm{y}_{t}=$ MPE on output, $p_{t}=$ MPE on inflation

Table 3 reports on the short run coefficient. As can be seen, in general the results for short run are consistent with those in the long run which indicates that more developed financial system tends to reduce the MPE on output in the short run (using money supply as a policy variable). The same results obtained for MPE on inflation where both policy variables (interest rates and money supply) indicate that more developed financial system tends to reduce the inflation rate. This signals that monetary policy becomes more effective in stabilising inflation rate in response to more developed financial system. However, in the short run, MPE on output (using interest rates as a policy variable) becomes more effective in response to stock market development. This indicates that a more developed stock market in the economy is necessary to speed up the transmission mechanism of monetary policy.

Table 4 represents the diagnostic test results. The diagnostic test conducted for normality, serial correlation, and heteroscedasticity were found to be satisfactory, suggesting that the estimated model is acceptable. The full results of the test are available upon request. Figure 1 shows the result of CUSUMQ test for the model to elucidate the long-run relationship between the variables. The CUSUMQ plot lies within the confidence interval and is significant at 5\% level. This indicates that all the coefficient and the error correction model are stable. The result of the CUSUMQ test for the model on the MPE on output growth, in response to money supply $y_{t}^{m}$, slightly exceeds the $5 \%$ significance level. The plot of CUSUMQ however is restored towards the criteria bands. 
Danie Eirieswanty Kamal Basa et al.

Table 3

Short-run relationship

\begin{tabular}{lccccc}
\hline \multicolumn{3}{c}{ Dependent variable : output, $y_{t}$} & \multicolumn{3}{c}{ Dependent variable : inflation, $p_{t}$} \\
\hline $\begin{array}{c}\text { Independent } \\
\text { variables }\end{array}$ & $y_{t}^{r}$ & $y_{t}^{m}$ & $\begin{array}{c}\text { Independent } \\
\text { variables }\end{array}$ & $p_{t}^{r}$ & $p_{t}{ }^{m}$ \\
\hline lliq_liab & 0.0014 & $-0.0249^{* * *}$ & lliq_liab & $-0.1099^{* * *}$ & $-0.0478^{* * *}$ \\
& {$[0.6239]$} & {$[-6.6509]$} & & {$[-2.9041]$} & {$[-4.3497]$} \\
lstock_markcap & $0.0066^{* * *}$ & $-0.0076^{* *}$ & lstock_markcap & $-0.0899^{* * *}$ & $-0.0406^{* * *}$ \\
& {$[3.5139]$} & {$[-2.8131]$} & & {$[-4.6082]$} & {$[-3.3837]$} \\
lgfcf & $-0.0048^{* *}$ & $0.0083^{*}$ & lgfcf & $0.0092^{* *}$ & $0.0199^{*}$ \\
& {$[-2.5449]$} & {$[1.8927]$} & & {$[2.6732]$} & {$[1.7989]$} \\
ect (-1) & $-0.5750^{* * *}$ & $-0.2316^{* * *}$ & ect(-1) & $-1.0442^{* * *}$ & $-0.5023^{* * *}$ \\
& {$[-22.342]$} & {$[-14.124]$} & & {$[-7.9943]$} & $-19.0232]$ \\
\hline
\end{tabular}

Notes: The asterisks $\left({ }^{*}\right),\left({ }^{* *}\right)$, and $\left({ }^{* * *}\right)$ denote the statistically significant at $10 \%, 5 \%$ and $1 \%$ levels; the standard errors are in ( ) while t-statistics are in [ ]; $y_{t}=$ MPE on output; $p_{t}=$ MPE on inflation

Table 4

Diagnostic test

\begin{tabular}{llllll}
\hline \multicolumn{2}{c}{ Dependent variable : output $y_{t}$} & \multicolumn{2}{c}{ Dependent variable : inflation $p_{t}$} \\
\hline \multicolumn{1}{c}{$\begin{array}{c}\text { Diagnostic } \\
\text { test }\end{array}$} & \multicolumn{1}{c}{$y_{t}^{r}$} & \multicolumn{1}{c}{$y_{t}^{m}$} & \multicolumn{1}{c}{$\begin{array}{c}\text { Diagnostic } \\
\text { test }\end{array}$} & $p_{t}^{r}$ & $p_{t}{ }^{r}$ \\
\hline LM test & 1.8650 & 0.2642 & LM test & 0.1847 & 1.7984 \\
& $(0.0594)$ & $(0.6706)$ & & $(0.7665)$ & $(0.1008)$ \\
Heteroskedasticity & 1.1604 & 2.7472 & Heteroskedasticity & 1.0852 & -0.2493 \\
& $(0.3233)$ & $(0.0631)$ & & $(0.2882)$ & $(0.6041)$ \\
Normality & 2.1426 & 3.2098 & Normality & 0.1722 & 4.9315 \\
& $(0.6746)$ & $(0.2009)$ & & $(0.9174)$ & $(0.0849)$ \\
\hline
\end{tabular}

Notes: The standard errors are in () 

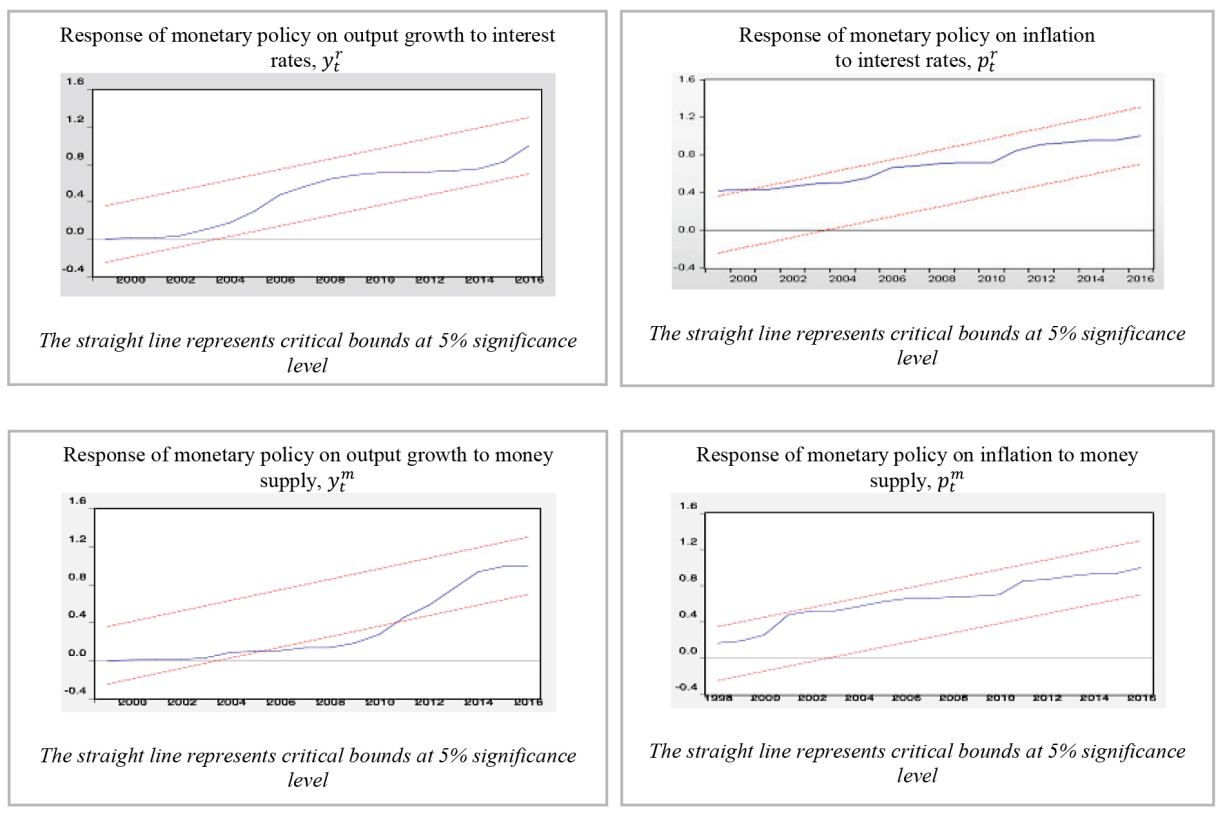

Figure 1. CUSUMQ test

\section{SUMMARY AND CONCLUSION}

Since the Malaysian financial system has experienced a major change in the last decade, the issue on whether FD influences the MPE becomes pertinent. Motivated by this issue and the dearth of past studies, this paper should accordingly provide a novel contribution to the relevant literature by providing new evidence on the role of FD on MPE in Malaysia through the use of time series data spanning from 1991 to 2016. MPE was generated using a structural VAR model, and the following ARDL model was used in investigating the role of FD (liquid liabilities and stock market capitalisation) on MPE.

The main findings revealed that the more developed financial system, i.e., a much deeper financial system, is associated with the decrease in MPE. The findings of this study are consistent with results from previous investigations. For example, Ma and Lin (2016) discovered a strong negative correlation between FD and the effects of monetary policy on output and inflation. This would indicate that the MPE tends to decline as the financial system becomes more advanced.

The policy implications from this study suggest that the BNM should monitor closely the level of FD in the country in order to ensure that they can leverage 
the monetary policy transmission mechanism in the economy. In line with the Financial Sector Blueprint (2011-2020), which stated that the financial sector is an enabler of economic growth, proper understanding on how FD affect MPE is crucial for BNM in designing its monetary policy strategy using quantitative and qualitative measures. Since the main finding revealed that the more developed financial system will hinder MPE, BNM should therefore be more selective in designing the FD strategy under the Financial Sector Blueprint (2011-2020). Secondly, since monetary policy (money supply and interest rates) becomes less effective in its response relative to a more develop financial system, BNM should thus utilise non-quantitative measures, such as moral persuasion in order to ensure that the final targets of monetary policy, such as price stability and long term sustainable of economic growth, are achievable. Thirdly, since gross fixed capital formation has improved the MPE (an increase in domestic output), a businessfriendly environment should therefore be implemented to encourage more fixed investments from domestic or foreign direct sources. This finding is also in line with the goal of the Financial Sector Blueprint (2010-2020) which stated that by 2020 the ratio of private investment to (GDP) should achieve $18 \%$. This would indicate the importance of fixed investment in complementing the level of FD ensuing from MPE.

\section{ACKNOWLEDGEMENTS}

We are grateful for the financial support from Faculty of Economics and Management, Universiti Kebangsaan Malaysia, Malaysia (project code EP-2015025).

\section{REFERENCES}

Ang, J.B. (2008). What are the mechanism linking financial development and economic growth in Malaysia? Economic Modelling, 25, 38-53. https://doi.org/10.1016/j. econmod.2007.04.006

Ang, J.B., \& McKibbin, W.J. (2007). Financial liberalization, financial sector development and growth: Evidence from Malaysia. Journal of Development Economics, 84, 215-233. https://doi.org/10.1016/j.jdeveco.2006.11.006

Ansari, M.I. (2002). Impact of financial development, money and public spending on Malaysia national income: An econometric study. Journal of Asian Economic, 13, 72-93. https://doi.org/10.1016/s1049-0078(01)00113-0

Arestis, P., Hadjimatheou, G., \& Zis, G. (1992). The impact of financial innovations on the demand for money in the UK and Canada. Applied Financial Economics, 2, 115-123. https://doi.org/10.1080/758536015 
Aysun, U., Brady, R., \& Honig, A. (2013). Financial frictions and the strength of monetary transmission. Journal of International Money and Finance, 32, 1097-1119. https://doi.org/10.1016/j.jimonfin.2012.09.003

Azali, M., \& Matthews, K. (1999). Money-income and credit-income relationships during the pre-and the post-liberalization periods: Evidence from Malaysia. Applied Economics, 31, 1161-1170. https://doi.org/10.1080/000368499323382

Bank Negara Malaysia. (2001). Financial sector masterplan 2001-2011. Kuala Lumpur: Bank Negara Malaysia.

Bank Negara Malaysia. (2011). Financial sector blueprint 2011-2020. Kuala Lumpur: Bank Negara Malaysia.

Beck, T., Lundberg, M., \& Majnoni, G. (2006). Financial intermediary development and growth volatility: Do intermediaries dampen or magnify shocks. Journal of International Money and Finance, 25, 1146-1167. https://doi.org/10.1016/j. jimonfin.2006.08.004

Bernanke, B., \& Gertler, M. (1995). Inside the black box: The credit channel of monetary policy transmission. Journal of Economic Perspectives, 9, 27-48. https://doi. org/10.3386/w5146

Berkelmans, L. (2005). Credit and monetary policy: An Australian SVAR. Research discussion paper, Reserve Bank of Australia, 2005-06.

Brown, R.L., Durbin, J., \& Evans, J.M. (1975). Techniques for testing the constancy of regression relations over time. Journal of the Royal Statistical Society B, 37, 149163. https://doi.org/10.1111/j.2517-6161.1975.tb01532.x

Carranza, L., Galdón Sánchez, J.E., \& Gómez, B.J. (2009). Understanding the relationship between financial development and monetary policy. Universidad De Navarra working paper, no. 14/06, November 2006. https://doi.org/10.1111/j.14679396.2010.00926.x

Cecchetti, S., \& Krause, S. (2001). Financial structure, macroeconomic stability and monetary policy. Working paper, National Bureau of Economic Research (NBER), no. 8354, January. https://doi.org/10.3386/w8354

Ciccareli, M., Maddaloni, A., \& Peydro, J. (2015). Trusting the bankers a new look at the credit channel of monetary policy. European Central Bank Working Paper No. 1228. https://doi.org/10.2139/ssrn.1767969

Demirgüç-Kunt, A., \& Levine, R. (1996). Stock market development and financial intermediaries: Stylized facts. World Bank Economic Review, 10, 291-322. https://doi.org/10.1093/wber/10.2.291

Demirgüç-Kunt, A., Feyen E., \& Levine, R. (2011). The evolving importance of banks and securities markets. Working paper 5805, World Bank Policy Review (WBPR). https://doi.org/10.1596/1813-9450-5805

Gomez, E., Vasquez, D., \& Zea, C. (2005). Derivative markets' impact on Colombian monetary policy. Banco De La Republica Colombia working paper. https://doi. org/10.32468/be.334

Gurley, J., \& Shaw, E. (1955). Financial aspects of economic development. American Economic Review, 45, 515-538.

Gurley, J., \& Shaw, E. (1967). Financial structure and economic development. Economic Development and Cultural Change, 15, 257-268. https://doi.org/10.1086/450226 
Hendry, D., \& Ericsson, N. (1991). Modeling the demand for narrow money in the United Kingdom and the United States. European Economic Review, 35(4), 833-881. https://doi.org/10.1016/0014-2921(91)90039-1

Ibrahim, M. (2005). Sectoral effect of monetary policy: Evidence from Malaysia. Asian Economic Journal, 19, 83-102.https://doi.org/10.1111/j.1467-8381.2005.00205.x

Karim, Z. A., Zaidi, M.A.S., \& Asri, N.M. (2008). Pembangunan kewangan dan pertumbuhan sektor-sektor ekonomi: Bukti empirikal di Malaysia. Jurnal Ekonomi Malaysia, 42, 65-89. https://doi.org/10.23917/jep.v7i1.3990

Karim, Z.A., Azman-Saini, W.N.W., \& Karim, B.A. (2011). Bank lending channel of monetary policy: Dynamic panel data study of Malaysia. Journal of Asia-Pacific Business, 12(3), 225-243. https://doi.org/10.1080/10599231.2011.570618

Karim, Z.A., Zaidi, M.A.S., \& Karim, B.A. (2013). Monetary policy shocks, financial constraints and firm-level equity return: Panel evidence. Jurnal Pengurusan, 39, 51-63. https://doi.org/10.17576/pengurusan-2013-39-05

Karim, Z.A., \& Karim, B.A. (2014). Interest rates targeting of monetary policy: An open economy SVAR study of Malaysia. Gadjah Mada International Journal of Business, 16(1), 1-22. https://doi.org/10.22146/gamaijb.5464

Kashyap, A., \& Stein, J. (1997). The role of banks in monetary policy: A survey with implications for the European Union. Economics Perspectives, 22(5), 2-18. https://doi.org/10.1257/aer.90.3.407

Kashyap, A., \& Stein, J. (2000). What do a million observations on banks say about the transmission of monetary policy? American Economic Review, 90, 407-428.

Kim, S., \& Roubini, N. (2000). Exchange rate anomalies in the industrial countries: A solution with a structural VAR approach. Journal of Monetary Economics, 45(3), 561-586. https://doi.org/10.1016/s0304-3932(00)00010-6

Krause, S., \& Rioja, F. (2006). Financial development and monetary policy efficiency. Emory Economics 0613, Department of Economics, Emory University, Atlanta.

Levine, R., \& Zervos, S. (1996). Stock market development and long-run growth. World Bank Economic Review, 10(2), 323-339. https://doi.org/10.1093/wber/10.2.323

Levine, R., Loayza, N., \& Beck, T. (2000). Financial intermediation and growth: Causality and causes. Journal of Monetary Economics, 46, 31-77. https://doi.org/10.1016/ s0304-3932(00)00017-9

Ma, Y., \& Lin, X. (2016). Financial development and effectiveness of monetary policy. Journal of Banking and Finance, 68, 1-11.

Meier, G.M., \& Seers, D. (1984). Pioneers in development. New York: Oxford University Press.

Mishra, P., Montiel, P.J., \& Spilimbergo, A. (2012). Monetary transmission in low-income countries: Effectiveness and policy implications. IMF Economic Review, 60(2), 270-302. https://doi.org/10.1057/imfer.2012.7

Mullineux, A. (1994). Financial innovation and monetary policy in the UK. Review of Policy Issues, 1(2), 29-44.

Pesaran, H.M., \& Shin, Y. (1995). Autoregressive distributed lag modelling approach to cointegration analysis. DAE Working Paper Series No 9514, Department of Applied Economics, University of Cambridge. https://doi.org/10.1017/ cbo9781139052221.011 
Pesaran, M.H., \& Shin, Y. (1999). An autoregressive distributed lag modelling approach to cointegration analysis. In S. Storm, (ed). Econometrics and economic theory in the 20th century. Cambridge: Cambridge University Press. https://doi.org/10.1002/ jae. 616

Pesaran, M.H., Shin, Y., \& Smith, R.J. (2001). Bounds testing approaches to the analysis of level relationships. Journal of Applied Econometrics, 16, 289-326. https://doi. org/10.1002/jae.616

Singh, S., Razi., A., Endut, N., \& Ramlee, H. (2007). Impact of financial market developments on the monetary transmission mechanism. Bank for International Settlements (BIS) working paper, no. 39.

Tang, H.C. (2006). The relative important of monetary policy transmission channels in Malaysia. CAMA Working Paper Series, Australian National University, Australia.

Taylor, M. (1987). Financial innovation, inflation and the stability of the demand for broad money in the United Kingdom. Bulletin of Economic Research, 39(3), 225-233. https://doi.org/10.1111/j.1467-8586.1987.tb00243.x

Xiaohui, G., \& Masron, T.A. (2014). Regional effects of monetary policy in China. Asian Academy of Management Journal, 19(1), 113-146.

Zaidi, M.A.S, \& Fisher, L.A. (2010). Monetary policy and foreign shocks: A SVAR analysis for Malaysia. Korea and The World Economy, 11(3), 527-550.

Zaidi, M.A.S., Karim, Z.A., \& Azman-Saini, W.N.W. (2013). Foreign and domestic shocks: Macroeconomic responses of ASEAN-3 countries. Global Economic Review, 42(3), 215-237. https://doi.org/10.1080/1226508x.2013.835900

Zaidi, M.A.S., Karim, Z.A., \& Zulkefli, Z. (2018). Impact of China on Malaysian economy: Empirical evidence of sign-restricted structural vector autoregression (SVAR) model. Asian Academy Journal of Management Journal of Accounting and Finance, 14(2), 25-44. https://doi.org/10.21315/aamjaf2018.14.2.2

Zaidi, M.A.S., \& Karim, Z.A. (2014). Impact of Singapore, US and Japanese macroeconomic shocks on Malaysian economy: A sign-restricted SVAR analysis. Jurnal Pengurusan, 21, 113-122. https://doi.org/10.17576/pengurusan-2014-41-10 